\title{
An Analysis of Social Cultural Change and the Renewal of Music Education Concept in China
}

\author{
Zhu JiaJun ${ }^{1, a}$, Chen Jun ${ }^{1, b}$ \\ ${ }^{1}$ Jiangxi Science \& Technology Normal University, Nanchang, Jiangxi, 330013, China \\ a20651816@qq.com, ${ }^{b} 974034152 @ q q . c o m$
}

Keywords: Social and cultural change;the idea of music education; renewal

\begin{abstract}
The progress of the times and the continuous development of society, politics, economy, culture and other aspects will follow a larger change in the music with the corresponding music education philosophy will be a certain change. The history, society and culture of our country have been undergoing numerous changes, and each period has its own concept of music education. The concept of music education in each period has led to the development of music culture in this period. , We study our social and cultural changes in various historical periods and their educational concept of music education, while for the new era of music education to update the corresponding recommendations.
\end{abstract}

\section{Introduction}

The new period music education belongs to the modern basic education of music, and this kind of education thought mainly comes from the western education thought, but very deeply reflects our country social culture transformation need. In the social culture, the values are a core content, the core content of the change will further promote the educational values of the update and play, so the culture is the carrier for the transmission and development of education, so we must master the social and cultural change To understand the concept of music education in the process of social and cultural change. According to this law and the needs of the times, we can update the concept of music education in China in a timely manner so as to better carry out music teaching activities and improve the efficiency of music teaching. Music literacy.

\section{Under the traditional ethics morals view, to set up "the morality is beautiful" the music education view}

In the past a long period of time, the concept of China's music education by the traditional ethical concepts. The traditional music more emphasis on the pursuit of emotional impact on the soul. In the process of education and teaching, music emotion is regarded as a kind of moral value emotion or aesthetic emotion education. Under this idea, music education fully embodies certain moral and emotional value. On the one hand, the traditional concept of music education in modern music into the essence of the fine tradition, until today still will have far-reaching impact, on the other hand also promoted the cultural heritage of China five thousand years. In this process, it is worth mentioning that the Warring States period Confucius put forward the "no class to teach" point of view, this view essentially reflects the national education thinking, but at the time of "national education" education background, this idea There is no way to implement.

\section{Oriental learning the West, The Beginning of Music Basic Education in China}

"Oriental learning the West" for music education has a landmark significance [1]. First, it succeeded in opening the windows of China's understanding of the world, so that China began to correct, comprehensive understanding and understanding of the world. At that time the reformers attached great importance to education, put forward the significance of education, but also a clear level of national education will be the future development of education path [2]. Even in the development of national education, reformers have made great efforts, to a certain extent, to achieve certain results. 
For example, in 1891 Kang Youwei wrote the "Datong book" proposed in the school set up music courses, which from the political level for the development of Chinese music basic education laid the foundation. 1901 Shanghai Nanyang subsidiary primary school officially opened a music class, which is currently known as the earliest music school. This is also the beginning of modern government-run and private music education.

\section{The May Fourth New Culture Movement, and the educational concept of "civic moral education"}

This period, the new culture movement in full swing, this movement for the "civic moral education" the emergence of a great role in promoting. At the time, Cai Yuanpei put forward the militarist democracy, materialism, civic morality, world outlook and aesthetic education education policy. This policy has been recognized and supported by all sectors of society, further promoting the development of China's basic music education. During this period the Ministry of Education for the implementation of a number of reforms, and promulgated the "school rules to implement the rules" and other systems, and actively advocate music must preserve virtue, cultivate sentiment. In essence, this is the music education history is a significant initiative. Music education in this period is closely linked with social and cultural changes. Music education has become an important part of national culture.

\section{Anti-Japanese national salvation period, stimulated the enthusiasm of the national war, promoted the development of basic music education}

The anti - Japanese singing movement during the Anti - Japanese War profoundly affected the music education in our country. Beginning in 1935, the primary and secondary school teachers and students by extending the form of anti-Japanese national salvation songs, expression and transmission of patriotic democratic ideology. For example, Nie Er creation of "Volunteers March", melodic passion, called on people to rise up to war, save the nation. This period of music is mainly anti-Japanese national salvation songs, anti-Japanese music throughout the country, the national anti-Japanese passion, anti-Japanese songs from the music classroom spread to the community. This stage of music education not only inspired the national war enthusiasm, but also promoted the development of basic music education.

\section{The Educational Idea of "Taking Russia as Teacher" in the Early Period of New China}

The founding of the People 's Republic of China marked the victory of China' s new - democratic revolution. The central government formulated the value orientation of "taking Russia as a teacher". Imitation of the former Soviet Union to determine the music education system and content, and promote the upgrading of the quality of education, part of the academic and even today, thus forming a "European technology as the center" of the education pattern. However, the overall Europeanization of music teaching has a negative impact. But in general to promote the healthy development of music education. Not only to help students establish a correct outlook on life, at the same time leaders at all levels to give full attention to music education, music teaching hardware facilities to increase capital investment, teaching environment has been greatly improved for the follow-up education has laid a good Foundation.

\section{During the period of extreme leftism, music education was neglected}

Under the influence of the extreme left thinking, due to various political factors, our teaching concept gradually changed. Since 1957, China has experienced a long left-wing agitation, this ultra-left thinking and effective promotion of the teaching concept of change. But in the actual operation, because of the misunderstanding of thinking, serious cause of the old education, a reasonable core, and further triggered a great lack of traditional Chinese teaching work. The concept of teaching only 
refers to the moral education, intellectual education, sports kinetic energy, etc., but completely ignored the aesthetic education of students [3]. Art education in educational institutions was recognized as a collection of feudalism and capitalism by the people of a great exclusion, not only to remove the curriculum directly, but also directly to its curriculum ban. A large number of art teachers were forced to divert, art thinking has been greatly limited, seriously distorted the morality, and thus greatly affected the overall quality of our civilization.

\section{Since the reform and opening up, established the "aesthetic as the core" of music education}

In the new period of reform and opening up, all schools in the country have further strengthened their ideological and political work, and strictly implemented the policy of comprehensive development of moral, intellectual, physical, and aesthetic work to cultivate students into a new era of socialist construction. Music education is a kind of phenomenon of human culture. The existence and development of music education fully embodies the social and cultural changes in different periods. However, no matter how strong the national culture is, the education of the country must be based on the culture of the nation. China's education in a hundred years has undergone tremendous changes in modern education has also undergone a certain change, the traditional cultural deposition on its cultural heritage has an inherent role in the decision. We must absorb the essence of traditional culture, positive innovation, development in line with the needs of the times the development of music education [4]. At the present stage, education is in the transitional stage. Our country actively advocates the development of quality education and has carried on the quality education reform for more than ten years. This educational concept has been widely supported and got a good development at the same time. We guide the quality of education center is a comprehensive development of students, requires students to moral, intellectual, physical, organic unity of the United States. At the same time for a complete person, the moral and intellectual body is not fragmented, is not a simple combination, but an organic unity of the whole, unified integration after the formation of a complete personality. A person's personality has its own merits and demerits of the decision. From the current situation of education reform, music education for students to improve the quality and ability to have a great role in the development of effective music education students can develop innovative ability to purify the hearts of students to promote the sound development of student personality, which Are unmatched by other teaching subjects, and this is also an important means to carry out quality education activities. Based on this, in the current educational practice, music education has been further expanded.

\section{Summary}

In summary, through the analysis of our country's social change and music concept change, we recognize the great significance of music education, but also understand the different educational thoughts of different periods. At the present period of social transformation, we carry out quality education, advocating " Core "educational philosophy greatly promote the development of social culture, the music education is conducive to the development of the quality and ability of students, is conducive to the cultivation of innovative spirit, is conducive to purify the soul of students, help students to build a complete Personality. In this regard, we must effectively grasp the law of social development in the actual educational activities, the use of advanced educational philosophy of organizing music education activities to promote the comprehensive development of people.

\section{References}

[1] Han Xunguo.Chinese social and cultural change and the concept of music education [J] Huang Zhong (China. Wuhan Conservatory of Music), 2005,02: 112-117.

[2] Guan Jianhua. 21st century, the concept of music education, the three changes [J]. Journal of Nanjing Arts Institute (Music and Performing Edition), 2008,02: 101-107. 
[3] Xie Fang. On the 1900-1920 school music education in China the concept and practice [J]. Music Research, 2014,06: 16-26.

[4] Li Haiou. On the concept of modern Chinese music education on the traditional Chinese music education inheritance [J] Dong Yue, 2016,07: 157-163. 